\title{
WINTER OILSEED-RAPE YIELD ESTIMATES FROM HYPERSPECTRAL RADIOMETER MEASUREMENTS
}

\author{
JAN PieKARCZYK \\ Adam Mickiewicz University, Institute of Physical Geography and Environmental Planning, Poznań, Poland \\ HanNa SulewSKa, GraŻyna SZYMaŃSKa \\ University of Life Science, Department of Soil and Plant Cultivation, Poznań, Poland
}

Manuscript received: September 25, 2010

Revised version: February 15, 2011

\begin{abstract}
PiekARCZYK J., SulewsKa H., SzYMAŃSKa G., 2011. Winter oilseed-rape yield estimates from hyperspectral radiometer measurements. Quaestiones Geographicae 30(1), Bogucki Wydawnictwo Naukowe, Poznań, pp. 77-84, 3 Figs., 3 Tabs. ISBN 978-83-62662-39-5. ISSN 0137-477X. DOI 10.2478/v10117-011-0007-z.

ABSTRACT. Spectral reflectance data can be used for estimation of plant biophysical parameters such as seed yield, related to the use of solar energy. A field experiment was conducted to investigate relationships between canopy reflectance and seed yield of winter oilseed rape sown on four different dates. Ground hyperspectral reflectance measurements were made using a hand-held radiometer and multispectral images were taken with a VIS-NIR camera. The different sowing dates generated a wide range of difference in crop spectral response and seed yields. The strongest relationships $\left(\mathrm{R}^{2}=0.87\right)$ between the yield and spectral data recorded by both sensors occurred at early flowering stages. Later, the presence of flowers caused a decline in the relationship between yield and spectral data especially in the visible (VIS) range. In the full flowering stage the strongest correlation $\left(R^{2}=0.72\right)$ with the yield showed vegetation indices of the near-infrared (NIR) bands.
\end{abstract}

KEYWORDS: Remote Sensing, ground hyperspectral measurements, winter oilseed rape, yield.

Jan Piekarczyk, Adam Mickiewicz University, Institute of Physical Geography and Environmental Planning, Dzięgielowa 27, 61-680 Poznań, Poland, e-mail:piekjan@amu.edu.pl

\section{Introduction}

Remote sensing data can provide non-destructively and instantaneously quantitative information about agricultural crops. Spectral reflectance measurements can be used to monitor plant conditions (Gibbons \& Freudenberger 2006, Ji-Hua \& Bing-Fang 2008), estimate plant nutrient status (Nguyen \& Byun-Woo 2006, Zhao et al. 2005), detect abiotic and biotic stresses (Clay et al.
2006, Gröll et al. 2007), estimate plant growth rate (Beck et al. 2007) and forecast crop yields (Galvao et al. 2009, Li et al. 2007). In order to make better use of spectral data, the vegetation indices are calculated using crop reflectance at differing wavelengths. The most widely used vegetation index is normalized difference vegetation index (NDVI) which is the difference of the reflectance in the red and near-infrared (NIR) wavelength divided by their sum (Rouse et al. 1973). In the 
red portion of the electromagnetic spectrum the vegetation strongly absorbs incident radiation, while in the NIR portion green leaves are highly reflective due to leaf structure. The recent availability of hyperspectral data provides a promising source for applications in agriculture. Hyperspectral remote sensing is the measurement of spectral "signatures" using data of high spectral resolution (e.g., $1 \mathrm{~nm}$ ) within the range of 400 $2500 \mathrm{~nm}$ (Price 1990). The higher spectral information content of hyperspectral data compared to broadband data, may allow more accurate analyses of the canopy spectral response.

Remote sensing have been used to forecast crop yields in various approaches of which the most simple methods are based on statisticalempirical relationships between the yield and vegetation indices (Thenkabail et al. 2002, Casa \& Jones 2005). The final yield is correlated with the values of vegetation indices (eg. NDVI) recorded at the single dates or their time integral at specific times during the season (Yang \& Anderson 1996). To increase the accuracy of yield forecasting the spectral data should be combined with input data from the agrometeorological models. These integrated data are used for estimating biophysical parameters of plants related to the use of solar energy such as leaf area index (LAI) or percent vegetation cover. Galvão et al. (2009) studied the possibility of using satellite Hyperion hyperspectral images to estimate the yield of soybean obtaining a high correlation ( $\mathrm{r}$ $=0.74$ ) between the values of vegetation indices and weight of harvested seed. The relationship between cotton yield and hyperspectral data and the best time for its estimation was determined on the basis of ground-based measurements by Zhao et al. (2007). Developed by Li et al. (2007) model using artificial neural network structure enabled the prediction of yields of maize and soybean on the basis of satellite data from MODIS sensor in regional scale, with an accuracy of $85 \%$. Doraiswamy et al. (2004) also studied the possibility of using MODIS satellite data for forecasting yields and ground reflectance measurements were performed to calibrate the developed model. The usefulness of aerial photographs, performed in the visible (VIS) and NIR ranges several times during the growing season for forecasting yields of maize has been studied as well (Chang et al.
2003). On a regional scale, a crop yield estimation was carried out based on vegetation indices derived from AVHRR/NOAA satellite image data (Prasad et al. 2006). Dąbrowska et al. (2008) presented the method to monitor the growth and yield of cereals on the basis of AVHRR/NOAA images in Polish conditions.

To date, few studies have been reported on the use of remote sensing for assessing winter oil-seed rape biophysical parameters. Increasing in recent years, cultivated area of oilseed rape in Poland, linked to the intensification of biofuel production, should lead to the development of methods to control the condition of crops and forecasting yields.

The goal of this study was to determine the possibility of winter oilseed-rape yield forecasting on the basis of vegetation indices acquired in ground hyperspectral measurements. The impact of sowing date on the oilseed rape crop spectral characteristics after overwintering was assessed as well.

\section{Materials and Methods}

The study was conducted on plots at the Experimental Farm in Złotniki of the University of Life Sciences in Poznań, Poland $\left(52^{\circ} 29^{\prime} \mathrm{N}, 16^{\circ} 48^{\prime} \mathrm{E}\right)$. The winter oilseed rape was sown in randomized 48 plots on four dates: 14 and 25 August and 4 and 15 September 2008 (SD1, SD2, SD3 and SD4 respectively), at row spacing of $0.35 \mathrm{~m}$ and sowing direction from west to east. Fertilizer was applied as top dressing to provide in the autumn (in $\mathrm{kg} \mathrm{ha}^{-1}$ ) $25 \mathrm{~N}, 21.8 \mathrm{P}$ and $103.75 \mathrm{~K}$ and in the spring $112.2 \mathrm{~N}$. In autumn the crop was sprayed with the herbicide Butisan Star 416 SC at a rate equivalent to $31 \mathrm{ha}^{-1}$ and with Fusilade Forte EC $\left(1 \mathrm{~h} \mathrm{ha}^{-1}\right)$. Insecticides and fungicides were applied according to official recommendations. Crop growth stages were determined according to BBCH-Identification keys (Stauss 1994).

Hyperspectral measurements and multispectral images were taken in April and May 2009 on three dates: 19 and 30 April and 12 May. Reflectance spectra of the winter rape plots were collected by a portable ASD FieldSpec Pro spectroradiometer (Analytical Spectral Devices Inc., Boulder, CO, USA). Reflectance was measured at 
wavelengths ranging from 350 to $1000 \mathrm{~nm}$ with the spectral resolution of $3 \mathrm{~nm}$ and from 1000 to $2500 \mathrm{~nm}$ with $10 \mathrm{~nm}$ resolution. The radiometer had a $25^{\circ}$ field of view and the distance between the optical head and the upper plant leaves was $2 \mathrm{~m}$. All spectral measurements were taken on cloudless days within one hour of solar noon. Reference panel (Spectralon) measurements were collected immediately before the luminance measurements from the oilseed rape plots. Canopy reflectance factors were calculated as the ratio of the reflected radiance from vegetation to that reflected from a reference panel (Robinson \& Biehl 1979). The four spectra were obtained for each plot at nadir direction and then were averaged. Vegetation indices were calculated using reflectance factors in the wavelengths which had been applied earlier by many authors: $550 \mathrm{~nm}$ and $870 \mathrm{~nm}$ (Gitelson et al. 2005), $675 \mathrm{~nm}$ (Thomas \& Oerther 1972), $700 \mathrm{~nm}$ (Haboudane et al. 2002), $775 \mathrm{~nm}$ (Clevers et al. 2002), $820 \mathrm{~nm}$ (Hunt and Rock 1989), $980 \mathrm{~nm}$ (Osborne et al. 2002), $1070 \mathrm{~nm}$ (Ustin et al. 2002), $1195 \mathrm{~nm}$ (Zhao et al. 2004), $1260 \mathrm{~nm}$ (Malthus et al. 1993). In the study the following hyperspectral vegetation indices were calculated:

$$
\begin{gathered}
\mathrm{NDVI}_{550,775}=\left(\mathrm{R}_{775}-\mathrm{R}_{550}\right) /\left(\mathrm{R}_{775}-\mathrm{R}_{550}\right), \\
\mathrm{NDVI}_{820,980}=\left(\mathrm{R}_{980}-\mathrm{R}_{820}\right) /\left(\mathrm{R}_{980^{-}}-\mathrm{R}_{820}\right), \\
\text { SRWI}=\mathrm{R}_{870} / \mathrm{R}_{1260^{\prime}}
\end{gathered}
$$

$$
\begin{gathered}
\mathrm{NDVI}_{1070,1195}=\left(\mathrm{R}_{1070}-\mathrm{R}_{1195}\right) /\left(\mathrm{R}_{1070}-\mathrm{R}_{1195}\right), \\
\operatorname{NDVI}_{675,775}=\left(\mathrm{R}_{775}-\mathrm{R}_{675}\right) /\left(\mathrm{R}_{775}-\mathrm{R}_{675}\right)
\end{gathered}
$$

where $\mathrm{R}_{550^{\prime}}, \mathrm{R}_{675^{\prime}}, \mathrm{R}_{700^{\prime}}, \mathrm{R}_{775^{\prime}}, \mathrm{R}_{820^{\prime}}, \mathrm{R}_{870^{\prime}}, \mathrm{R}_{980^{\prime}}, \mathrm{R}_{1070^{\prime}}$ $\mathrm{R}_{1195^{\prime}} \mathrm{R}_{1260^{\prime}}$ are reflectance factors in the 550, 675, 700, 775, 820, 870, 980, 1070, 1195 and $1260 \mathrm{~nm}$ bands, respectively.

Multispectral images of the plots were taken on three dates: 7, 19 and 30 April with the digital camera ADC3 TETRACAM which has a sensor recording reflected radiation in the three broadband channels: G (green 520-600 nm), R (red 630-690 nm) and NIR (near-infrared 760-920 $\mathrm{nm}$ ) with an image size of 2048 by 1536 pixels ( 3.2 $\mathrm{mPel})$. From the each ADC image two broadband vegetation indices were calculated:

$$
\mathrm{NDVI}_{\mathrm{ADC}}=(\mathrm{NIR}-\mathrm{R}) /(\mathrm{NIR}+\mathrm{R}) \text {, }
$$

Soil Adjusted Vegetation Index $\mathrm{SAVI}_{\mathrm{ADC}}=1.5^{*}(\mathrm{NIR}-\mathrm{R}) /(\mathrm{NIR}+\mathrm{R})+0.5$, Huete (1988)

where R and NIR are mean values of all pixels of the pictures from red and NIR channels of ADC camera.

\section{Results and discussion}

\begin{tabular}{|c|c|c|c|c|}
\hline Date & $\begin{array}{l}\text { Sowing date } \\
\text { (SD) }\end{array}$ & Growth stage & ВBCH & $\begin{array}{l}\text { Day after sowing } \\
\text { (DAS) }\end{array}$ \\
\hline 7 April & 1 & \multirow{4}{*}{ Stem elongation } & \multirow{4}{*}{$35-36$} & 218 \\
\hline & 2 & & & 228 \\
\hline & 3 & & & 237 \\
\hline & 4 & & & 248 \\
\hline \multirow[t]{4}{*}{19 April } & 1 & \multirow{2}{*}{ Flowering } & \multirow{2}{*}{60} & 230 \\
\hline & 2 & & & 240 \\
\hline & 3 & \multirow{2}{*}{ Inflorescence emergence } & \multirow{2}{*}{$55-57$} & 249 \\
\hline & 4 & & & 260 \\
\hline \multirow[t]{4}{*}{30 April } & 1 & \multirow{2}{*}{ End of flowering } & \multirow{2}{*}{69} & 241 \\
\hline & 2 & & & 251 \\
\hline & 3 & \multirow{2}{*}{ Full flowering } & \multirow{2}{*}{$65-67$} & 260 \\
\hline & 4 & & & 271 \\
\hline \multirow[t]{4}{*}{12 May } & 1 & \multirow{4}{*}{ Development of fruit } & \multirow{4}{*}{$73-74$} & 253 \\
\hline & 2 & & & 263 \\
\hline & 3 & & & 272 \\
\hline & 4 & & & 283 \\
\hline
\end{tabular}

At the beginning of the growing season the growth rates of plants sown at various dates were different and those sown earlier developed

Table 1. Stages of development according to BBCH scale and days after sowing (DAS) on four dates when spectral measurements were taken on plots sown on four dates (SD) 

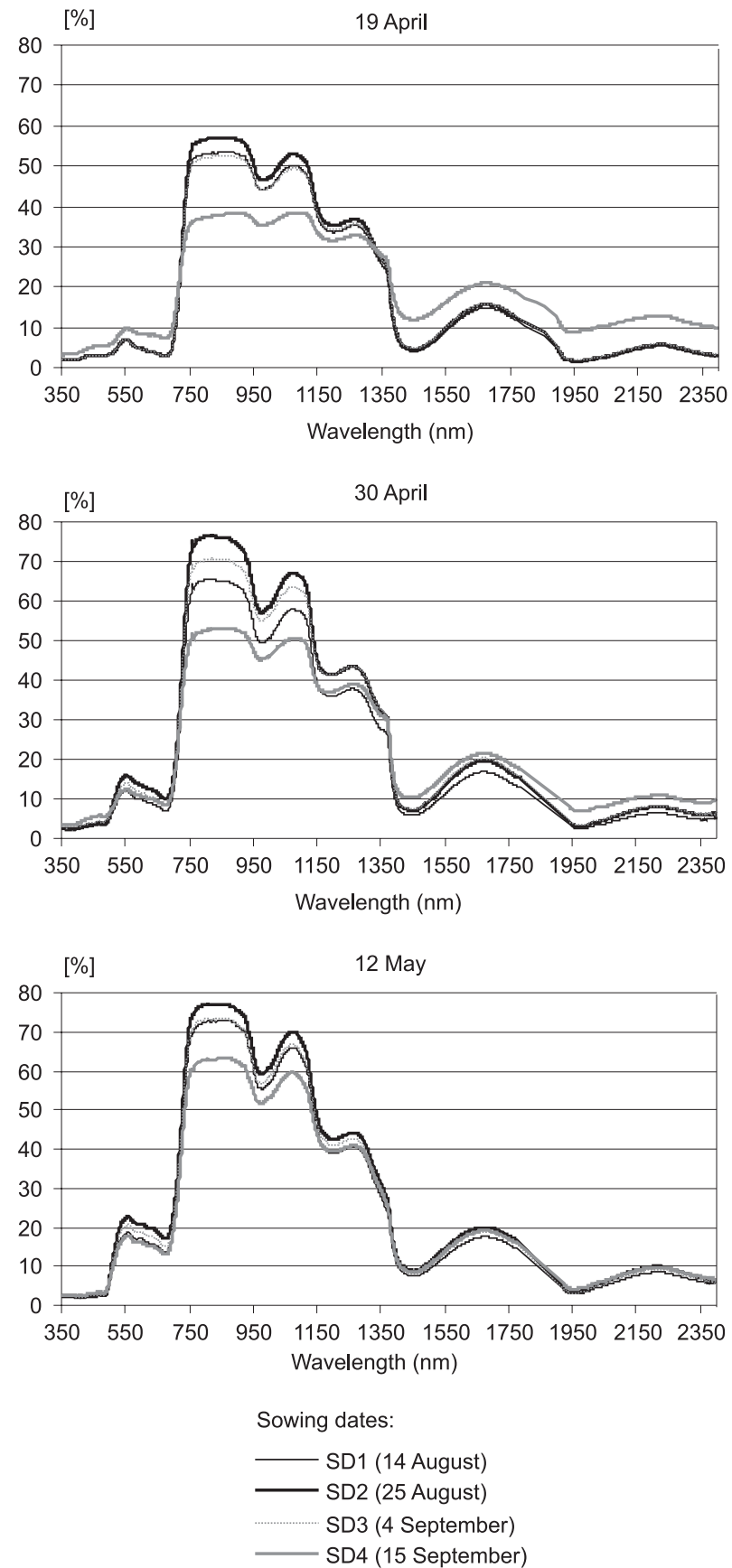

Fig. 1. Hyperspectral curves recorded at three dates, at plots of winter oilseed rape sown at four dates

more quickly and flowered earlier (Table 1). The differences in growth rates resulted in the diversification of the spectral characteristics (Fig. 1). On plots sown at the latest date (SD4) the rape oilseed plants developed least in autumn, and therefore in the spring, after the start of vegetation, their growth was the least dynamic. Relatively low biomass in the plots of SD4 caused the lowest reflectance in the near-infrared (NIR)
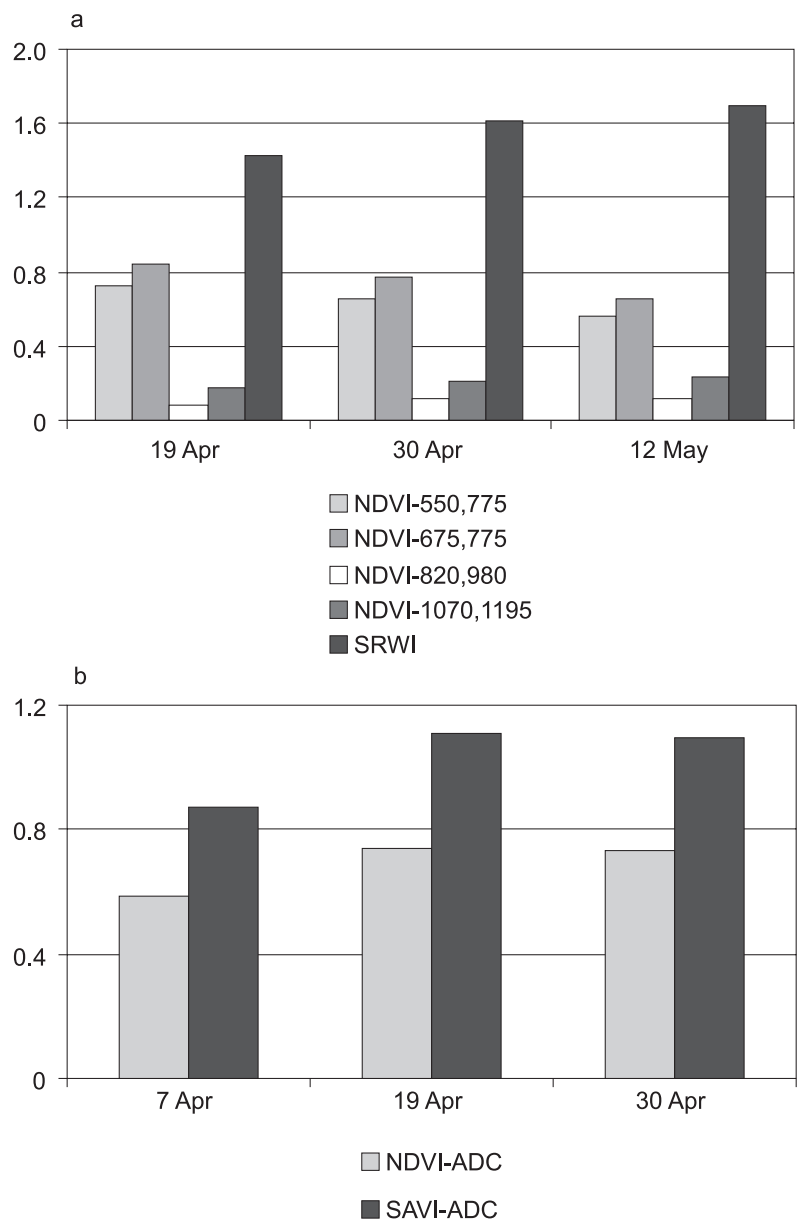

Fig. 2. Mean values of a) four hyperspectral (ASD) and b) two broadband (ADC) vegetation indices of winter oilseed rape

wavelengths from those plots and the highest in the visible (VIS) and the shortwave infrared (SWIR) wavelengths compared to the reflectance recorded from the plots sown on the earlier dates. Most dynamic plant growth resulted in the highest reflectance in NIR wavelengths throughout the period when measurements were performed was observed in the plots sown on August 25 (SD2). This date is considered optimal for sowing of winter oilseed rape in the Wielkopolska region of. At the flowering stage, which started in late April, a reflectance in the VIS wavelengths from the plots SD2 was the highest what resulted from the presence of greatest number of flowers in the field of view of the radiometer sensor.

The sowing date of plants had a huge influence on growth, development and consequently on seed yield of winter oilseed rape. The highest yield (53.9 dt/ha) was obtained from plots SD2, the lowest (40.0 dt/ha) from plots SD4 and for 
the remaining plots, SD1 and SD3, the yield was 49,3 i 50,8 dt/ha, respectively. Fathi et al. (2003) found a decrease in seed yield of oilseed rape by $52 \%$ at sowing delayed by seven weeks.

The vegetation indices calculated from the both VIS and NIR wavelength bands increased until flowering in the second decade of April due to an increase of biomass (Fig. 2.). During the flowering, the vegetation indices decreased due to the yellow petals of the flowers which are strongly reflective in VIS wavelengths and transparent in NIR wavelengths. Behrens et al. (2006) similarly reported a significant reduction of the vegetation indices in the flowering stage. The indices calculated using solely NIR spectral bands $\left(\mathrm{NDVI}_{820,980}\right.$ and SRWI) increased continuously until the stage of development of fruit because of still increasing plant biomass.

Oilseed rape plots with plants sown in different dates showed the greatest variation in the
NIR bands of the reflectance spectra at 780-1200 $\mathrm{nm}$. When the plants were in the flowering stage (on 30 April), values of NDVI ${ }_{1070,1195}$ differed between all four SD (Table 2). At the beginning of the flowering stage differences between all plots were less pronounced, especially for indices that were calculated using the reflectance factors in VIS bands $\left(\mathrm{NDVI}_{550,775}\right.$ and $\left.\mathrm{NDVI}_{675,775}\right)$. The values of these indices differed significantly only between the plots with the SD1 and SD2.

In order to estimate the possibility of predicting the yield of oilseed rape on the basis of hyperspectral and broadband spectral data at the beginning of the growing season the mean values of the analyzed vegetation indices from 48 plots with the seed yield were compared. The strongest correlation between the yield of oilseed rape and spectral data recorded by both sensors, ASD and ADC, occurred on 19 April and later this relationship weakened as oilseed rape plants were

Table 2. The mean values of five hyperspectral (ASD) and two broadband (ADC) vegetation indices from the plots of winter oilseed rape sown at four different dates. Means followed by the same letter within each index and date are not significantly different

\begin{tabular}{|c|c|c|c|c|c|c|c|}
\hline \multirow{2}{*}{ Sowing date } & NDVI $_{550,775}$ & NDVI $_{675,770}$ & NDVI $_{820,980}$ & NDVI $_{1070,1195}$ & SRWI & NDVI & SAVI \\
\hline & \multicolumn{7}{|c|}{ April 7} \\
\hline 1 & - & - & - & - & - & $0.68 \mathrm{ab}$ & $1.02 \mathrm{a}$ \\
\hline 2 & - & - & - & - & - & $0.65 a$ & $0.98 \mathrm{a}$ \\
\hline 3 & - & - & - & - & - & $0.73 b$ & $1.09 \mathrm{a}$ \\
\hline 4 & - & - & - & - & - & $0.28 c$ & $0.42 b$ \\
\hline \multirow[t]{2}{*}{ LSD } & - & - & - & - & - & 0.08 & 0.11 \\
\hline & \multicolumn{7}{|c|}{ April 19} \\
\hline 1 & $0.78 a$ & $0.90 \mathrm{a}$ & $0.10 \mathrm{a}$ & $0.20 \mathrm{a}$ & $1.56 a$ & $0.82 a$ & $1.21 \mathrm{a}$ \\
\hline 2 & $0.78 a$ & $0.91 a$ & $0.10 \mathrm{a}$ & $0.20 \mathrm{a}$ & $1.58 \mathrm{a}$ & $0.84 a$ & $1.26 \mathrm{a}$ \\
\hline 3 & $0.77 a$ & $0.90 \mathrm{a}$ & $0.09 b$ & $0.19 b$ & $1.51 \mathrm{~b}$ & $0.82 a$ & $1.22 \mathrm{a}$ \\
\hline 4 & $0.58 b$ & $0.66 b$ & $0.03 c$ & $0.10 \mathrm{c}$ & $1.17 \mathrm{c}$ & $0.50 \mathrm{~b}$ & $0.74 b$ \\
\hline \multirow[t]{2}{*}{ LSD } & 0.03 & 0.04 & 0.01 & 0.01 & 0.04 & 0.07 & 0.1 \\
\hline & \multicolumn{7}{|c|}{ April 30} \\
\hline 1 & $0.69 a$ & $0.81 \mathrm{a}$ & $0.14 \mathrm{a}$ & $0.24 a$ & $1.77 \mathrm{a}$ & $0.73 a b$ & $1.10 \mathrm{ab}$ \\
\hline 2 & $0.65 b$ & $0.76 b$ & $0.14 \mathrm{a}$ & $0.37 b$ & $1.77 \mathrm{a}$ & $0.71 \mathrm{ab}$ & $1.07 \mathrm{ab}$ \\
\hline 3 & $0.66 \mathrm{bc}$ & $0.78 \mathrm{ab}$ & $0.12 b$ & $0.21 c$ & $1.64 b$ & $0.77 \mathrm{a}$ & $1.15 \mathrm{a}$ \\
\hline 4 & $0.60 \mathrm{~d}$ & $0.71 c$ & $0.07 c$ & $0.15 \mathrm{~d}$ & $1.37 \mathrm{c}$ & $0.71 b$ & $1.06 \mathrm{~b}$ \\
\hline \multirow[t]{2}{*}{ LSD } & 0.03 & 0.03 & 0.01 & 0.02 & 0.06 & 0.06 & 0.09 \\
\hline & \multicolumn{7}{|c|}{ May 12} \\
\hline 1 & $0.59 a$ & $0.68 \mathrm{a}$ & $0.14 \mathrm{a}$ & $0.26 a$ & $1.82 \mathrm{a}$ & - & - \\
\hline 2 & $0.55 b$ & $0.63 b$ & $0.13 a$ & $0.25 \mathrm{ab}$ & $1.77 \mathrm{ab}$ & - & - \\
\hline 3 & $0.56 \mathrm{ab}$ & $0.66 \mathrm{ab}$ & $0.13 a$ & $0.24 b$ & $1.72 \mathrm{~b}$ & - & - \\
\hline 4 & $0.56 \mathrm{ab}$ & $0.65 \mathrm{ab}$ & $0.09 b$ & $0.20 c$ & $1.55 c$ & - & - \\
\hline LSD & 0.04 & 0.05 & 0.01 & 0.02 & 0.07 & - & - \\
\hline
\end{tabular}

LSD - least significant difference at $\mathrm{P}=0.01$. 
Table 3. The values of the coefficients of determination (R2) obtained for the linear regression models between the seed yield of oilseed rape and values of five hyperspectral and two broadband vegetation indices at four measurement dates

\begin{tabular}{|c|c|c|c|c|c|}
\hline Vegetation index & April 7 & April 19 & April 30 & May 12 & Cumulative indices \\
\hline \multicolumn{7}{|c|}{ ASD } \\
\hline NDVI $_{550,775}$ & - & 0.86 & 0.35 & 0.01 & 0.57 \\
\hline NDVI $_{675,775}$ & - & 0.82 & 0.35 & 0.01 & 0.58 \\
\hline NDVI $_{820,980}$ & - & 0.83 & 0.70 & 0.66 & 0.79 \\
\hline NDVI $_{1070,1195}$ & - & 0.82 & 0.72 & 0.63 & 0.79 \\
\hline SRWI $_{870,1260}$ & - & 0.83 & 0.71 & 0.41 & 0.74 \\
\hline \multicolumn{7}{|c|}{ ADC } \\
\hline NDVI & 0.71 & 0.88 & 0.02 & - & 0.52 \\
\hline SAVI & 0.71 & 0.87 & 0.02 & - & 0.51 \\
\hline
\end{tabular}

in flowering stage (Table 3). After 19 April, a significant correlation showed only the indices of the NIR bands.

To improve the relationship between the spectral data and the seed yield the average values of the vegetation indices acquired at the two consecutive measurement dates were multiplied by the number of days that have divided these dates and the values obtained were summarized receiving the cumulative vegetation indices. The correlation between the yield of rapeseed and cumulative indices were weaker than that obtained on 19 April. Application by Serrano et al. (2000), the cumulative simple ratio index $(680 / 900 \mathrm{~nm})$ significantly increased the value of the coefficient of determination for the relationship between spectral data and yield of wheat. However, in case of rape oilseed the cumulative indices are less effec- tive in estimating yields because of the rape flowers, which appear at a time when the biomass of plants is very high. Among the analyzed cumulative indices the most yield-related were indices of the NIR bands: $\mathrm{NDVI}_{820,980}, \mathrm{NDVI}_{1070,1195}$ and SRWI giving the determination coefficients of $\mathrm{R}^{2}=0.79$, 0.79 and 0,74, respectively. Galvão et al. (2009) also found the strongest correlation between the yield of different varieties of soybean and Hyperion satellite vegetation index of the NIR bands 854 and $1245 \mathrm{~nm}$.

Verification of the obtained regression models were carried out using the values of the vegetation indices $\mathrm{NDVI}_{675,775}$ and $\mathrm{NDVI}_{\mathrm{ADC}}$ calculated on the basis of spectral data recorded by sensors ASD and ADC, respectively. Regression equation describing the relationship between yield and vegetation indices derived from measurements

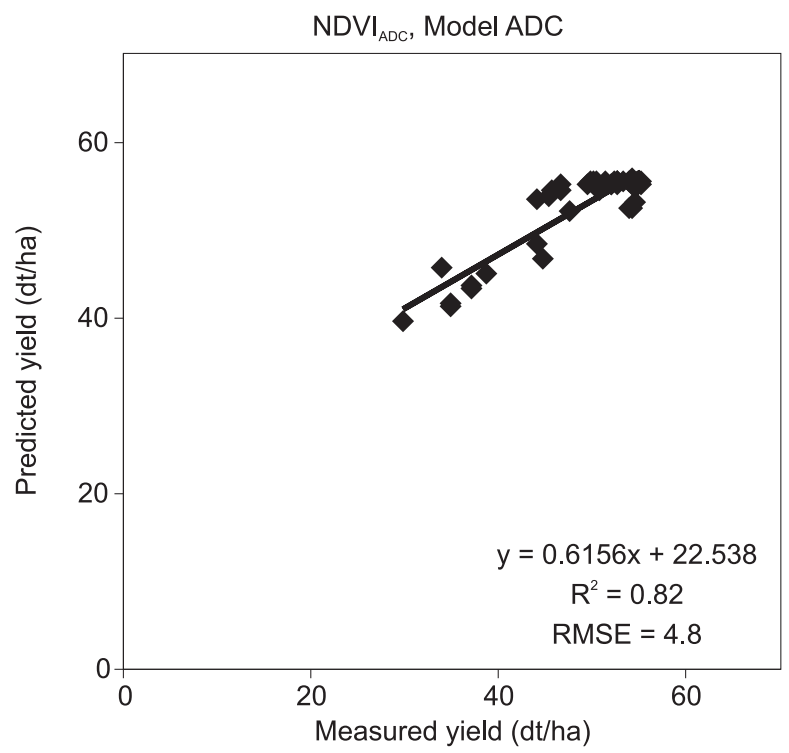

Fig. 3. Relationships between the measured and predicted yield of oilseed rape calculated using models ADC and ASD and the NDVI index values obtained on 19 April $(n=48)$. 
performed with ASD radiometer (model ASD) on April 19, was used to calculate the predicted yield on the basis of the vegetation index values derived from camera images taken by ADC on the same day (Fig. 3.) Similarly, the regression model calculated from the correlation between yield and indices from the ADC images (ADC model) were verified using the values of vegetation indices obtained from the ASD data. The ASD model gave a higher coefficient of determination than the ADC model but also the greater standard error.

\section{Conclusions}

Large spectral variations observed in plots of winter oilseed rape at the beginning of the growing season indicates the possibility of using aerial photographs and satellite images to identify the parts of the area under cultivation of different plant densities. The resulting high correlation between seed yield and ground spectral data indicates the possibility of the use of aerial and satellite images to predict the oilseed rape yield in the early growth stages, if the later development of plants during the growing season will not be disturbed. The most appropriate time to predict yield in the initial part of the growing season was the second decade of April when the plants were in early stages of flowering. Later, the presence of flowers caused a decline in the relationship between yield and spectral data especially in the visible range. Flowers in a much lesser extent weakening the correlation between the indices of the NIR bands and yield. The results of this study indicate that the vegetation indices acquired at the beginning of a growing season can be used as input data for the plant growth models, which provide estimates of potential yields.

\section{References}

Beck P.S.A., Jonsson P., Høgda K.-A., Karlsen S.R., EKLUndH L. \& SKIDMORE A.K., 2007. A ground-validated NDVI dataset for monitoring vegetation dynamics and mapping phenology in Fennoscandia and the Kola peninsula. International Journal of Remote Sensing, 28(19): 4311-4330.

Behrens T., Muller J. \& Diepenbrock W., 2006. Utilization of canopy reflectance to predict properties of oilseed rape (Brassica napus L.) and barley (Hordeum vulgare L.) during ontogenesis. European Journal of Agronomy, 25: 345-355, DOI:10.1016/j.eja.2006.06.010.

CASA R. \& Jones H.G., 2005: LAI retrieval from multiangular image classification and inversion of a ray tracing model. Remote Sensing of Environment, 98: 414 - 428, DOI: 10.1016/j.rse.2005.08.005

Chang J., Clay D.A., Dalsted K., Clay S. \& O’Neill M., 2003. Corn (Zea mays L.) Yield Prediction Using Multispectral and Multidate Reflectance. Agronomy Journal, 95: 14471453.

Clay D.A., Kim K., Chang J., Clay S.A. \& Dalsted K., 2006. Characterizing Water and Nitrogen Stress in Corn Using Remote Sensing. Agronomy Journal, 98: 579-587, DOI: 10.2134/agronj2005.0204.

Clevers J.G.P.W., De Jong S.M., Epema G.F., Van Der Meer F.D., BAKKER W.H., SKIDMORE A.K., \& Scholte K.H., 2002. Derivation of the red edge index using the MERIS standard band setting. International Journal of Remote Sensing, 23(16): 3169-3184.

DąbrowsKa-ZielińsKa K., CioŁkosz A., Budzý́ska M., KowaLIK W., 2008. Monitorowanie wzrostu i plonowania zbóż metodami teledetekcji. Problemy Inżynierii Rolniczej, 4: 45-54.

Doraiswamy P.C., Hatfield J.L., Jacksona T.J., Akhmedova B., Prueger J. \& Sterna A., 2004. Crop condition and yield simulations using Landsat and MODIS. Remote Sensing of Environmen, 92: 548-559.

Fathi G., Siadat S.A. \& Hemaiaty S.S., 2003. Effect of sowing date on yield and yield components of three oilseed rape varieties. Acta Agronomica Hungarica, 51(3): 249-255.

Galvão L.S., Roberts D.A., Formaggio A.R., Numata I. \& Breunig F.M., 2009. View angle effects on the discrimination of soybean varieties and on the relationships between vegetation indices and yield using off-nadir Hyperion data. Remote Sensing of Environment, 113: 846-856, DOI:10.1016/j.rse.2008.12.010.

Gibbons P. \& Freudenberger D., 2006. An overview of methods used to assess vegetation condition at the scale of the site. Ecological Management \& Restoration, 7(S1): 10-17, 10.1111/j.1442-8903.2006.00286.x.

Gitelson A.A., Vina A., RundQuist D.C., Ciganda V., \& ArkeBAUER T.J., 2005. Remote estimation of canopy chlorophyll content in crops. Geophysical Research Letters, 32: L08403 DOI:10.1029/2005GL022688.

Gröll K., Graeff S. \& Claupein W., 2007. Use of Vegetation indices to detect plant diseases. Agrarinformatik im Spannungsfeld zwischen Regionalisierung und globalen Wertschöpfungsketten, Referate der 27. GIL Jahrestagung, 5.-7. März 2007, Stuttgart, Germany.

Haboudane D., Miller J.R., Tremblay N., Zarco-Tejada P.J., DeXTraze L., 2002. Integrated narrow-band vegetation indices for prediction of crop chlorophyll content for application to precision agriculture, Remote Sensing of Environment, 81: 416-426.

Huete A.R., 1988. A soil-adjusted vegetation index (SAVI). Remote Sensing of Environment, 25: 295-309.

Hunt, E. R., \& Rock, B. N., 1989. Detection of changes in leaf water content using near and middle-infrared reflectances. Remote Sensing of Environment, 30: 43-54.

Ji-HuA M.\& Bing-Fang W., 2008. Study on the crop condition monitoring methods with remote sensing. The International Archives of the Photogrammetry, Remote Sensing and Spatial Information Sciences, 37(B8): 945-948.

Li A., Liang S., Wang A. \& QIN J., 2007. Estimating Crop Yield from Multi-temporal Satellite Data Using Multivariate 
Regression and Neural Network Techniques. Photogrammetric Engineering \& Remote Sensing, 73(10): 1149-1157.

Malthus T.J., Andrieu B., Danson F.M., Jaggard K.W. \& SteVEN M.D., 1993. Candidate high spectral resolution infrared indices for crop cover. Remote Sensing of Environment, 46: 204-212.

NGuyen H.T. \& Byun-Woo L., 2006. Assessment of rice leaf growth and nitrogen status by hyperspectral canopy reflectance and partial least square regression. European Journal of Agronomy, 24: 349-356.

Osborne S.L., Schepers J.S., Francis D.D. \& Schlemmer M.R., 2002. Detection of phosphorus and nitrogen deficiencies in corn using spectral radiance measurements. Agronomy Journal, 94: 1215-1221.

Prasad A.K., Chai L., Singh R.P. \& Kafatos M., 2006. Crop yield estimation model for Iowa using remote sensing and surface parameters. International Journal of Applied Earth Observation and Geoinformation, 8: 26-33, DOI:10.1016/j. jag.2005.06.002.

PRICE J.C., 1990. On the information content of soil reflectance spectra. Remote Sensing of Environment, 33: 113-121.

RoBINSON B.F. \& BIEHL L.L., 1979. Calibdue to ration procedures for measurements of reflectance factor in remote sensing field research. Proceedings SPIE, 196: 16-26.

Rouse J.W. JR., HaAs R.H., Schell J.A., DeERING D.W., 1973. Monitoring vegetation systems in the Great Plains with ERTS, In: Proceedings of the Earth Research Technical Satellite-1 Symposium. Goddard Space Flight Center, Washington, DC, pp. 309-317.

Serrano L., Fillela J. \& Penuelas J., 2000. Remote sensing of biomass and yield of winter wheat under different nitrogen supplies. Crop Science, 40: 723-731.

Stauss R., 1994. Compendium of growth stage identification keys for mono- and dicotyledonous plants. Extended $\mathrm{BBCH}$ scale. Ciba-Geigy AG, Postfach, Basel.
Thenkabail P.S., Smith R.B. \& De-Pauw E., 2002. Evaluation of narrowband and broadband vegetation indices for determining optimal hyperspectral wavebands for agricultural crop characterization. Photogrammetric Engineering, 68(6): 607-621.

Thomas J.R. \& Oerther G.F., 1972. Estimating nitrogen content of sweet pepper leaves by reflectance measurements. Agronomy Journal, 64: 11-13.

Ustin S.L., Roberts D.A., Gardner M., \& Dennison P., 2002. Evaluation of the potential of Hyperion data to estimate wildfire hazard in the Santa Ynez Front Range, Santa Barbara, California. Proceedings of the 2002 IEEE IGARSS and $24^{\text {th }}$ Canadian Symposium on Remote Sensing, Toronto, Canada, 24-28 June 2002 (Piscataway, NJ: IEEE), pp. 796-798.

YANG, C. \& ANDERSON, G.L., 1996. Determining within-field management zones for grain sorghum using aerial videography. 26th Int. Symp on Remote SVIH. Environ. 2529 March. Vancouver, BC, Canada, pp. 606-611.

Zhao C-J., Zhou Q., WANG J. \& HuAng W-J., 2004. Band selection for analysing wheat water status under field conditions using relative depth indices (RDI). International Journal of Remote Sensing, 25(13): 2575-2584.

Zhao D., RedDya K.R., KaKani V.G. \& Reddy V.R., 2005. Nitrogen deficiency effects on plant growth, leaf photosynthesis, and hyperspectral reflectance properties of sorghum. European Journal of Agronomy, 22: 391-403.

Zhao D., Reddy K.R., KaKani V.G., Read J.J. \& Koti S., 2007. Canopy reflectance in cotton for growth assessment and lint yield prediction. European Journal of Agronomy, 26:335-344, DOI:10.1016/j.eja.2006.12.001. 